\title{
Health advocates assail Canada's asbestos stance
}

$\mathrm{T}$

he Canadian government's ongoing support of the export of chrysotile asbestos has not only sullied Canada's global reputation, say health and environment advocates from around the world, but has undermined an international convention created to promote the responsible trade of hazardous chemicals.

Representatives from 126 countries attended the United Nations' Rotterdam Convention in Rome, Italy from Oct. 27-31 to discuss, among other things, adding chrysotile asbestos to a list of hazardous chemicals. The Canadian government has come under considerable criticism for its support of exporting the substance, which many health experts claim causes mesothelioma and lung cancer (CMAJ 2008;179[9]:886-7).

But chrysotile was not added to the list. Though Canadian representatives abstained from discussions, some who attended lay blame for the failure directly upon Canada, the only Western nation to oppose adding chrysotile to the list at the previous convention, 2 years ago.

"I'm afraid this is it for the Rotterdam Convention," says United States consultant Barry Castleman. "Canada has set a precedent that is now being followed, increasingly boldly, by all types of other countries. What started out as an effort to reach some sort of harmony and decency among nations has turned into anarchy."

Countries are not banned from importing substances on the Prior Informed Consent list but must acknowledge that they are aware they are receiving harmful materials. Canada did not officially oppose adding chrysotile but was active behind the scenes, says Castleman. "It's indefensible, what Canada has done. Selling asbestos is one thing, but the idea of not being willing to obtain prior informed consent before you export it is another. It's like the people running the government are graduates of the nevergive-a-sucker-an-even-break school of business. It's really vicious. They're like the most rapacious private-sector types."

Other health advocates concurred that the Rotterdam Convention is now beyond repair. "In my opinion, this has killed the convention stone dead,"

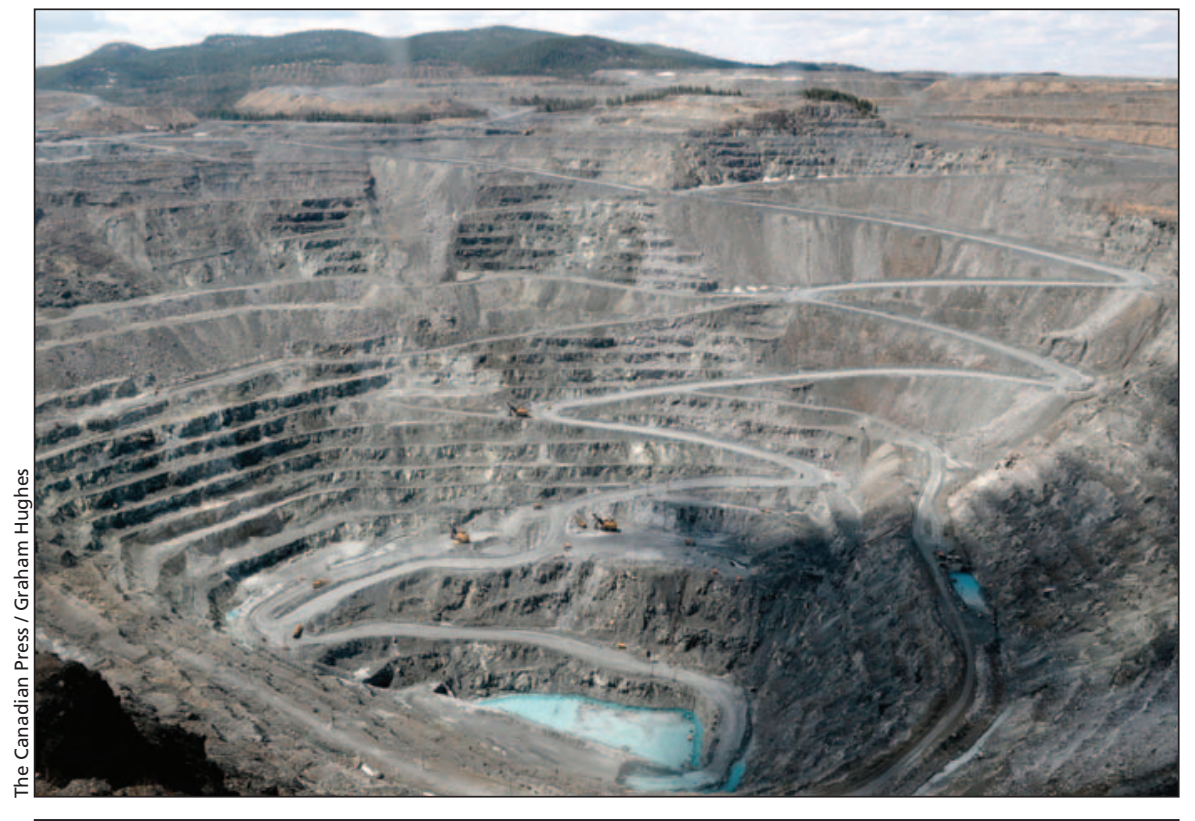

An asbestos mine just outside Thetford Mines, Quebec.

writes Laurie Kazan-Allen of England, the coordinator of the International Ban Asbestos Secretariat, in an email to CMAJ. "Overseas, the reputation of Canada as a nation previously well respected has been indelibly tarnished."

Tony Whitson, chair of the Asbestos Victims Support Groups Forum UK, echoed that sentiment in another email. "It beggars belief that elsewhere the truth is falsified and the prestigious international Rotterdam Convention is now shorn of any credibility."

Like Castleman, Whitson believes Canada's role in promoting the use of chrysotile in poorer nations is reprehensible. Canada is sacrificing lives "on the altar of crude commercial gain, and in doing so is rightly condemned before the developed nations who have banned all forms of asbestos. Canada in this respect is a pariah nation."

India, Pakistan and Vietnam are the main importers of chrysotile from Canada. At the convention, they were the most vocal opponents of declaring the substance dangerous.

Though less pessimistic about the convention's future, Gopal Krishna, coordinator of Ban Asbestos Network of India, was discouraged by his country's position. "The convention has definitely suffered a setback."
Canadians, "in their naked lust for profit, are willing to sacrifice whatever reputation Canada has as a civilized nation," he added.

But not all agree that the Rotterdam failure will have negative consequences. John Bridle, head of the United Kingdom-based Asbestos Watchdog, claims that the worldwide movement to ban chrysotile is fraught with fraud and corruption. Campaigns to ban asbestos are often backed by parties that stand to profit, he says, such as companies that produce asbestos alternatives.

Bridle claims white asbestos is no more carcinogenic than contraceptive pills, alcoholic beverages and other common products, and the global hysteria over the product is unwarranted. "If it went into the PIC [Prior Informed Consent] list," he says, "it would make things worse."

Paul Lapierre, vice-president of public affairs and cancer control at the Canadian Cancer Society, disagrees. Adding chrysotile to the dangerous substances list is overdue, he says. "It was a missed opportunity for the Canadian government to show leadership." - Roger Collier, CMAJ

DOI:10.1503/cmaj.081806 